Research Article

\title{
Coffee Landscape of Banyuwangi Geopark: Ecology, Conservation, and Sustainable Tourism Development
}

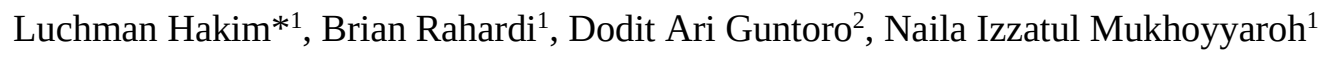 \\ ${ }^{1}$ Department of Biology, Faculty of Mathematics and Natural Sciences, Brawijaya University, Malang 65145, \\ Indonesia \\ ${ }^{2}$ Agency for Conservation of Natural Resources, East Java Office, Bandara Juanda, Surabaya 61253, Indonesia
}

Article history:

Submission July 2021

Revised July 2021

Accepted September 2021

*Corresponding author:

E-mail: luchman@ub.ac.id

\begin{abstract}
Coffee landscape is one of the crucial element of Banyuwangi Geopark, East Java. Coffee landscape plays an essential role in supporting the sustainable ecosystem in Banyuwangi Geopark. A number of studies have already examined ways to develop and preserve the coffee landscape and its biodiversity, especially in coffee cultivated under agroforestry system. This paper aims to describe the ecology of coffee landscapes in Banyuwangi, identify the problems and opportunities for preservation and biodiversity conservation, explore the possibilities of integrating coffee and tourism, and provide recommendations to preserve the coffee landscape and its biodiversity. Field survey, literature studies and interviews with farmers, tourism consultants, local travel planner, and local guides were conducted to get comprehensive data and information of the tourism potential of coffee landscape ecosystems. All these data were analyzed using descriptive analysis. Results of the study showed that Banyuwangi was home to numerous state-, private-, and peasant-owned coffee orchards. Coffee agroforestry had already been established for a long time, contributing to biodiversity conservations. Coffee cultivation was a common practice among communities, which later inspired the creation of a coffee festival. The high number of tourism attractions located in the geopark area coupled with the trend in tourism development, there was potential in integrating coffee into tourism. Important actions have to be done first, and these were: mapping and describing coffee orchard distribution, enhancing peasant capacity in coffee cultivation, introducing and strengthening sustainable tourism principles, and establishing regulation to ensure the preservation and conservation of coffee cultural landscapes. The outcome of analyses can be used to provide guidelines for the management of coffee landscape in the Banyuwangi Geopark area in future.
\end{abstract}

Keywords: Coffee agroforestry, Geopark management, Sustainable Coffee Landscape, Tourism development

\section{Introduction}

Coffee landscape has been identified as one of the important attributes of cultural landscapes in Banyuwangi, East Java. Coffee landscapes have been developed after coffee cultivation, which was initiated by the Dutch colonial company in the eastern area of Java Island. The first coffee cultivation emerged in Blawan, Ijen Plateau, in 1774. The high-quality coffee produced from Blawan has paved the way for its vast development in the eastern area of Java. It was said that the Dutch have developed coffee estates in many areas, in- fluencing local communities in eastern Java to start cultivating coffee. Recently, the coffee cluster that is composed of Banyuwangi, Jember, and Bondowoso has been identified as an important coffee cluster in Mt. Ijen area [1-3].

There are techniques available for coffee cultivation, ranging from full-sun monoculture to polyculture under agroforestry technique $[4,5]$. Coffee cultivation under agroforestry regimes has been reported to contribute to biodiversity conservation. Numerous studies have confirmed that coffee 
agroforestry system is a habitat for a diverse community of plants, birds, insects, and small mammals. The biodiversity of coffee agroforestry ecosystem is especially important to the rural community in Java. Within the agroforestry system, people cultivate numerous multipurpose plant species to support households in their daily lives $[6,7]$.

Coffee cultivation under agroforestry regime has been a significant practice among the communities living in the rural areas of Banyuwangi. The challenge faced by conservationist is therefore how to promote coffee agroforestry ecosystem as tourism attractions. The conservation and development of coffee landscapes as a potential asset for community-based tourism development are crucial to support the Banyuwangi Geopark [2]. Coffee agroforestry landscapes contribute significantly in establishing a sustainable ecosystem in the geopark area, especially in provisioning, regulating, and supporting cultural services [8,9]. However, the coffee landscape as an instrument component of geopark system in Banyuwangi has been few discussed. This study aims to identify ecological aspects of coffee landscapes and its problems and opportunities for conservation and generate people perceptions in integrating coffee in tourism.

\section{Material and Methods}

Field observations were conducted in Banyuwangi Regency, East Java. Banyuwangi Regency, an area of about $5,782 \mathrm{~km}^{2}$, is located in the eastern part of East Java Province. Ecologically, Banyuwangi is surrounded by ecosystems crucial for local and global biodiversity conservation, namely, Baluran National Park in the north, Mt. Ijen in the west, and Alas Purwo and Meru Betiri National Parks in the south. The ecosystems are ranging from coral reefs with high biodiversity level to mountain ecosystems [2]. Coffee is often cultivated in lowland and upland areas. Banyuwangi Regency has numerous outstanding geological sites, with some of them only found in this regency (i.e., Ijen crater and blue fire). The volcanic fertile land stretched from north (Mt. Ijen) to southwest (Mt. Arguporo) provides suitable lands for coffee cultivation.

To assess the potential area of coffee cultivation, we examined data from the office of agriculture in Banyuwangi Regency [10]. Based on document examination, Kalipuro, Songgon, Licin, and Glagah sub-regencies were selected for field survey. Field survey consist of plantation visitation to collect data related to general infor-mation of coffee ecology and ethno-ecological aspect of coffee cultivation. The research activity in each sites includes coffee species identification, plant species identification in agroforestry system and general physical aspect of coffee landscape description. In ethno-ecological survey, researchers asked each interviewee to mention plant composing agroforestry system and traditional techniques of coffee cultivation.

Interviews with farmers, tourism consultant, local travel planner, and local guide were conducted to get a comprehensive review of the tourism potential of coffee landscape ecosystems. We interviewed twenty farmers from to explore as-pects related to coffee culture cultivation, aspects related to problems with the coffee culti-vation, and willingness to preserve coffee cultivations.

To access the potentiality of coffee landscapes in tourism planning and development, a perception of tourism stakeholder is needed. These were done by interview with local tourism stakeholder in Banyuwangi. We interviewed two tourism consultants, four local travel planners, and five local guides to identify problems and challenges for the integration of tourism in coffee culture. Each interview took between 20 and 45 minutes. We verified field data and interview findings using the secondary data and literature. Data and information were discussed descriptively [3, 11, 12].

\section{Results and Discussion \\ Ecology of coffee landscapes}

Coffee landscape on the slope of Mt. Ijen is reportedly consisted of large coffee plantation managed by state and private enterprises and small coffee orchards owned and managed by local communities. Most of the recent coffee plantation dated way back during Dutch colonial era and still operate right now (Table 1) [10]. Banyuwangi has been identified as the center of coffee plantation, with Dutch coffee culture cultivation that started it all. Some old coffee-producing equipment and historical building for coffee processing were preserved; representing Banyuwangi is an important world coffee heritage site.

There are two types of coffee orchards managed by local community, coffee orchard, and home gardens. Based on the vegetation structure, the coffee landscape in the slope of Mt. Ijen can be classified into two categories, monoculture coffee 
Table 1. Coffee estate distribution in Banyuwangi Regency [10]

\begin{tabular}{llcl}
\hline \multicolumn{1}{c}{ Plantation } & Area (ha) & Location (sub-regencies) & \multicolumn{1}{c}{ Main commodity } \\
\hline Bayu Kidul & $1,303.61$ & Songgon & Coffee, clove \\
Bayu Lor & 741.21 & Songgon & Coffee, clove, abaca \\
Barumanis & 81.43 & Kalibaru & Coffee \\
Bumisari & $1,189.81$ & Songgon & Coffee, clove, cocoa, coconut \\
Glen Falloch & 910.87 & Tegalharjo, Glenmore & Coffee, clove, cocoa, coconut \\
Glen More & $1,006.76$ & Sepanjang, Glenmore & Coffee, clove, cocoa, coconut, pepp \\
Glen Nevis & 857.52 & Kebunrejo, Kalibaru & Coffee, rubber \\
Gunung Trisno & 49.50 & Kalibaru Kulon & Coffee \\
Kalibendo & 822.96 & Kampung Anyar, Glagah & Coffee, clove, rubber \\
Kaliklatak & $1,013.53$ & Gombengsari, Kalipuro & Coffee, clove, cacao, rubber, horti- \\
& 171.76 & Karangsari, Sempu & Colture \\
Karangsari & $1,545.18$ & Glagah, & Sugarcane, coffee, gmelina wood \\
Lijen & 177.12 & Tamansari & Coffee \\
Sri Wulung III & $1,097.87$ & Sukamade, Meru Betiri & Coffee, rubber, cacao \\
Sukamade & 43.57 & Kalibaru Manis & Coffee \\
Sumber bendo & 144.43 & Kaliwaru & Coffee, cacao, horticulture \\
Sumber Pangestu & $4,932.83$ & Karang Harjo, Glenmore & Coffee, cacao \\
Treblasala &
\end{tabular}

Sources: Agriculture Office of Banyuwangi Regency (2018)

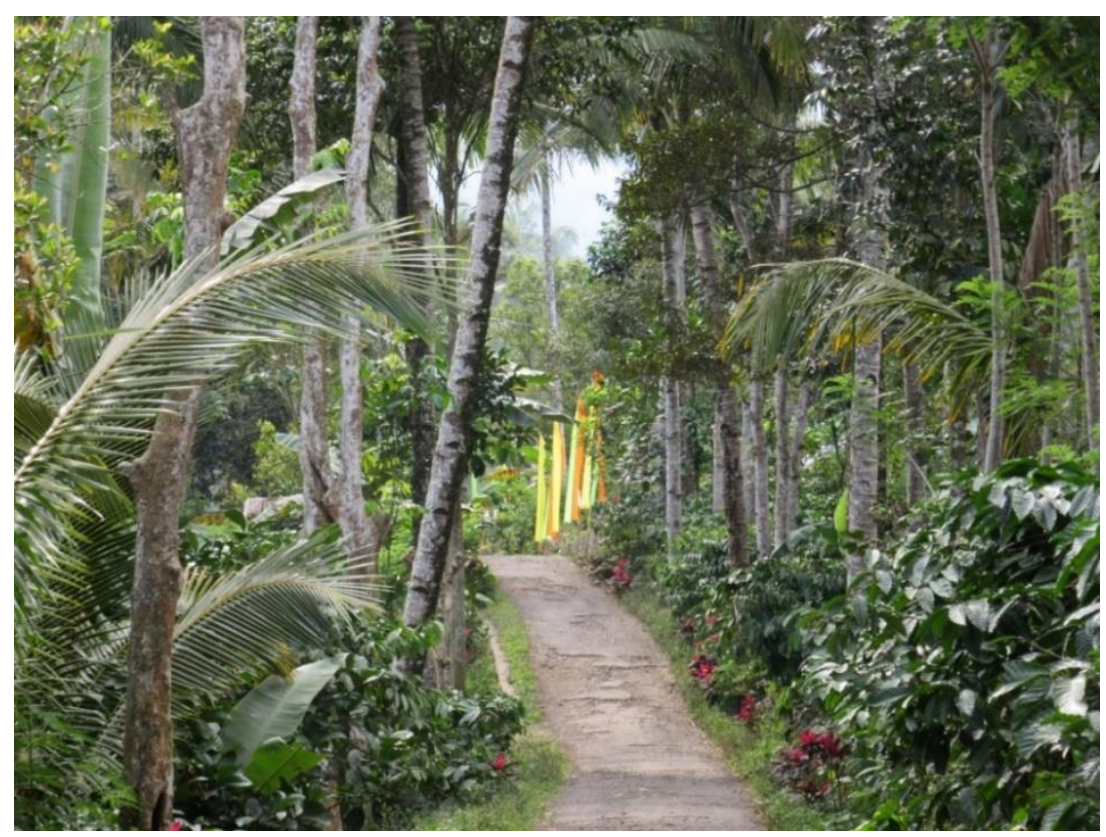

Figure 1. Coffee agroforestry system managed by local community in Banyuwangi

orchards and agroforestry coffee orchards. Both types of coffee cultivation was cultivated under shading tree species with different compositions (Figure 1). Cultivating coffee under shading trees has been reported to be common in Indonesia, and it is reported as sustainable agriculture practices $[5,7,13,14]$.

The coffee landscape in the slope of Banyuwangi has a unique and diverse flora. The primary crop species planted by the local people were Coffea liberica W. Bull ex Hiern (the Liberian coffee, locally called kopi glunduk, kopi ekselsa, kopi liberika, kopi nangka) and Coffea canephora Pierre ex A. Froehner (the robusta coffee, locally called kopi robusta). It is important to point out that these two species of coffee are distinct in plant habitus, performance, productivity, taste, price, and cultivation management. The robusta coffee is widely cultivated in state and private plantations for export. In Banyuwangi Regency, robusta coffee is the main crop in the communities living along the slope of Mt. Ijen and Mt. Raung. 
Some area is identified to be the center of robusta cultivation, including Kalibaru, Kalipuro, Songgon, Licin, Glenmore, and Glagah sub-regencies $[2,10]$.

Recent population of Liberian coffee was grown as native population without pruning techniques (Figure 2). Pruning is one of the basic techniques in coffee cultivation. These allow individual of Liberian coffee to grow like trees. The population of robusta coffee, conversely, was grown by pruning techniques and produce dwarf coffee plant population. Most of the robusta coffee population was grown through grafting techni-ques. Interestingly, people use root-stock for Liberian coffee and scion for robusta coffee in grafting. Based on previous reports, this grafting relatively produces more grains and relative resistance to drought. The use of Liberian coffee allows the capability of coffee grafting individual survive under dry periods. The common scions include $\mathrm{Tu}$ gusari, Kleres, and Koneha. Grafting is one of the methods used to increase grain bean productivity through selected superior scion insertion into individual root-stock [5].

Ethno-ecological practices of coffee landscapes have still been preserved by some peasant households, especially practiced by old men. According to respondents, coffee agroforestry system with high species will enhance income sustainabil-

ity more than the monoculture systems with low species number. A number of species was grown as shading trees for coffee, including Cocos nucifera, Swietenia macrophylla, Persea america- na, Durio zibethinus, Syzigium aromaticum, Myristica fragrans, Garcinia mangostana, etc. This practice is especially found in Liberian coffee orchard ecosystem. The cultivation of robusta coffee is often shaded by a limited number of woody trees species like Leucaena leucepala. The shading tree species seems similar with other coffee agroforestry models in Indonesia [15, 16]. Spice and herbs are significant components in coffee agroforestry ecosystem. Herbs and spices were grown to support the daily needs of the household, including plants as edible food, vegetables, fruit, spices, and food ingredients. Some of the herbs and spices have to be cultivated to generate household's cash income. It includes chili and pepper, which has relatively high price in traditional market.

Compost is generally applied in home garden to increase soil fertility. Compost was produced from cow and goat dung, litter, and organic waste which were composted naturally. Occasionally, chemical fertilizer was added to increase the productivity of robusta coffee, but it was absent of Liberian coffee. The use of compost is especially crucial in organic farming approach [17].

The diversity of plant in coffee agroforestry ecosystem provides an ideal habitat for birds, insect, and small mammal. So far, there are no comprehensive studies related to fauna diversity in coffee agroforestry ecosystem in Banyuwangi. However, it should be noted that birds and mammals are often observed in coffee agroforestry sys-

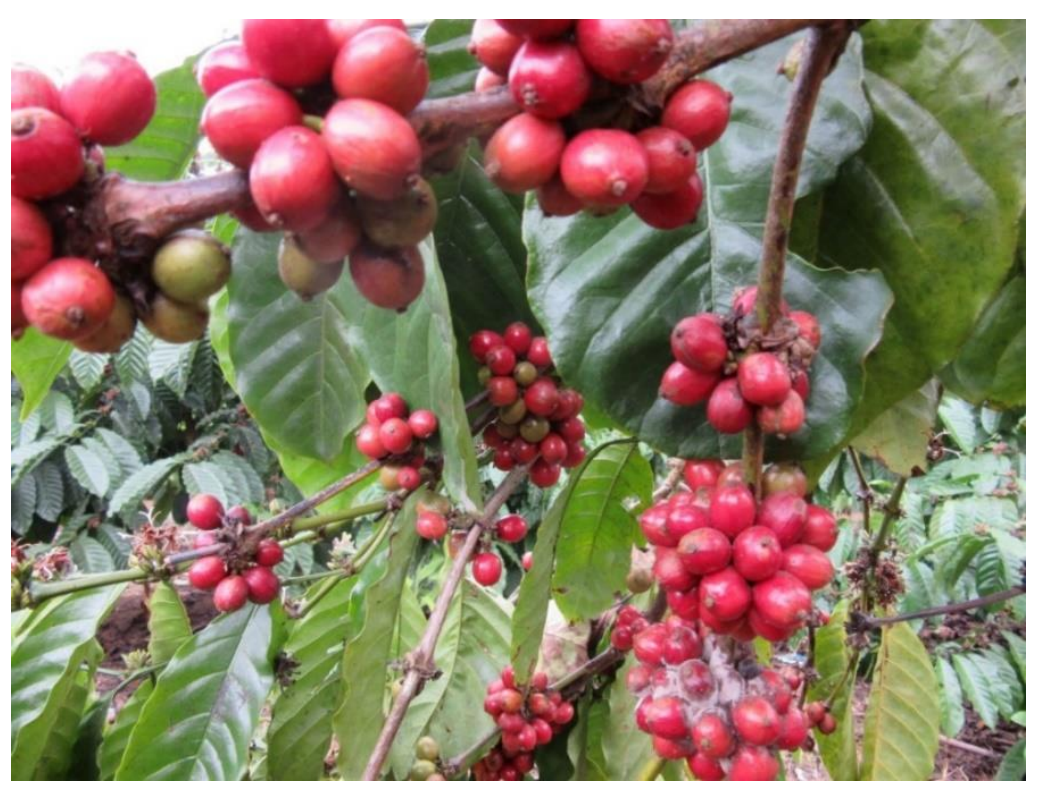

Figure 2. The Liberian coffee cultivated by local community in Grogol Village 
Table 2. Issues related to the future of coffee agroforestry

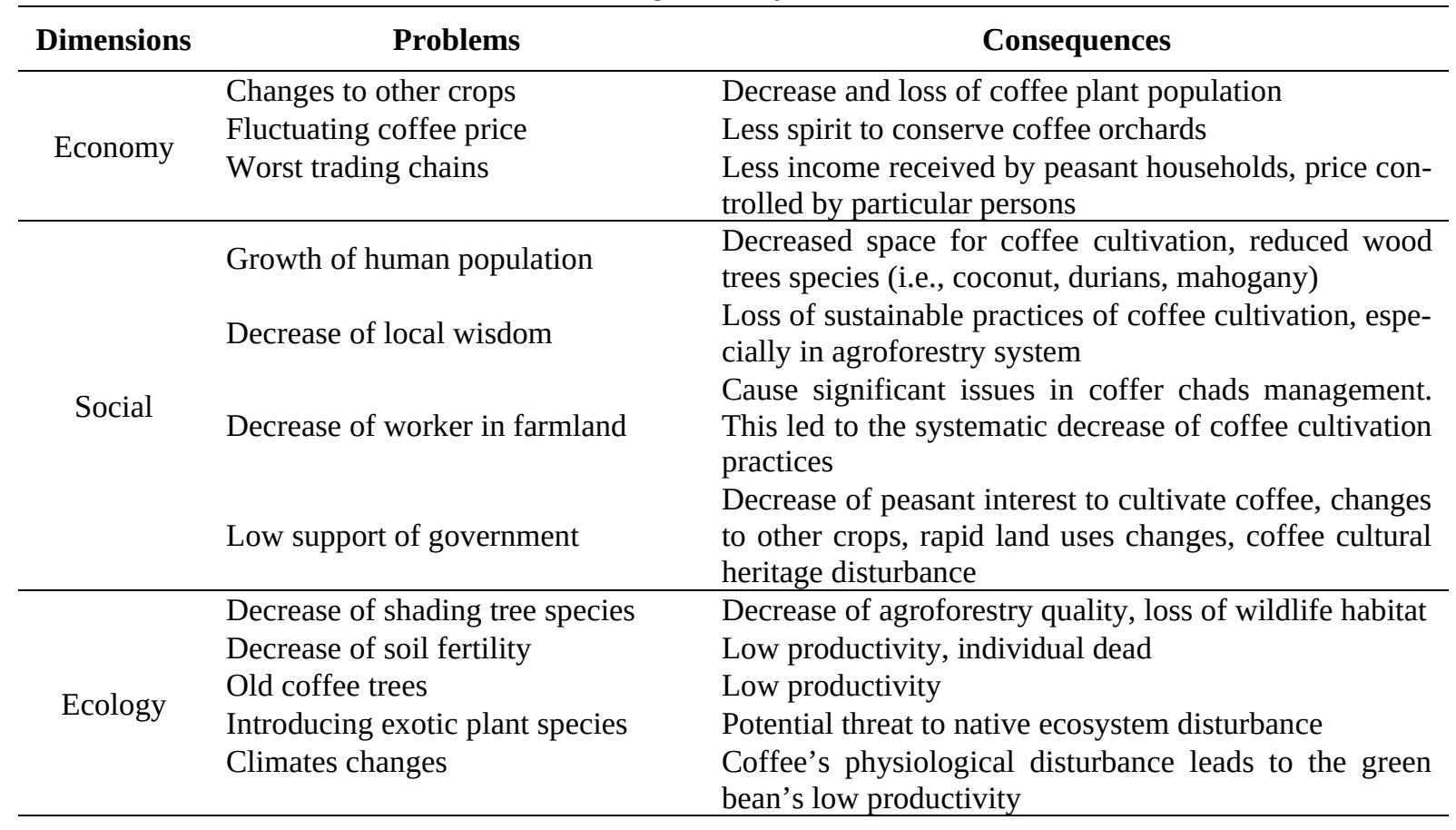

Table 3. Identified issues related to the integration of coffee into tourism development

\begin{tabular}{cl}
\hline Key aspect & \multicolumn{1}{c}{ Problems } \\
\hline \multirow{2}{*}{ Attraction } & $\begin{array}{l}\text { Coffee was viewed as crops plant with quality and quantity of green bean as the main product } \\
\text { (provisioning service). The potential value of cultural services has received less attentions. } \\
\text { Coffee culture was poorly studied, which eventually leads to poor data to establish attraction } \\
\text { Poor creativity and innovation to design and implement }\end{array}$ \\
\hline \multirow{3}{*}{ Amenity } & $\begin{array}{l}\text { Poor amenity support in making coffee as a tourism attraction } \\
\text { Few restaurant and coffee shops offer coffee produced by peasant } \\
\text { Few visitor centers for the coffee product exhibition are able to promote local coffee }\end{array}$ \\
\hline & $\begin{array}{l}\text { No spatial data available to integrate tourism amenity, transportation system, and center of } \\
\text { coffee cultivation } \\
\text { Poor corridor access to the center of coffee cultivation }\end{array}$ \\
\hline
\end{tabular}

tem including Paradoxurus hermaphroditus (Asian palm civet, locally called luwak), Callosciurus notatus (plantain squirrel, bajing), snakes, and bird species. These provide attractiveness to the coffee agroforestry in biodiversity conservation and tourism program. Asian palm civet has been identified as especially important in producing coffee luwak, the coffee green bean with high market price [18]. It was observed the presence of luwak coffee grain in the coffee agroforestry system attributed to the relative abundance of Asian palm civet. However, with the decrease of coffee orchards, increase of settlement in rural area, and illegal hunting by local community, it is recently very difficult to find civet. With the decrease of Asian palm civet population, the production of $l u-$ wak coffee under natural systems has seen a decre- ase. Since luwak coffee has been considered a charm to coffee consumers and has high market value, the decrease of luwak coffee collected from the wild would lead to the potential economic loss of coffee grain.

\section{The Preservation and biodiversity conservation of coffee landscapes: problem and opportunities}

Scholars point out that biodiversity conservation of coffee agroforestry ecosystem will have numerous positive impacts, including supporting ecotourism development. Another reason behind coffee landscape conservation was related to the germplasm conservation. Many species of coffee have been under extinction [19]. In Indonesia, it is especially important to consider the future of Liberian coffee. It should be pointed out that Libe- 
rian coffee shows a degree of variety in morphology, individual performance, and productivity. Nevertheless, there is no study available to identify potential diversity within Liberian coffee. This is especially crucial because only a few places in Indonesia remain to cultivate Liberian coffee. According to reports, threats to the Liberian coffee in Banyuwangi were often associated with rapid land use changes, less market interest, and low bean productivity.

The conservation of coffee agroforestry ecosystem in rural areas in developing countries has several significant constraints. Recently, the culture of local people in tropical developing countries is fast changing. According to informant in this study, globalization has affected the lives of local people, including those who lived in rural area. Changes in socioeconomic conditions have serious impact on biodiversity through the decrease of sustainable agriculture farming, including agroforestry. Emigration is another potential problem in sustaining the sustainability of coffee landscapes [20]. This is consistent with a recent finding that determines the trend of agricultural activity in Indonesia [21, 22]. A significant consequence of such situation includes the increasing number of abandoned lands and orchards. As per reports, recently, there are abandoned coffee orchards in Banyuwangi area. Some coffee-based plantation estates have also changed their production from coffee to sugar-canes and commercial woods.

Reports show that human population growth in rural area at the center of coffee orchards has reduced open and green spaces, especially home gardens. The loss of coffee agroforestry ecosystem is followed by decreases in biodiversity levels. Previous information reveals that diversity of recent birds species has also decreased compared with the past decades. It was also reported that Asian civet has rarely been found in coffee orchards. Changes of vegetation composition in coffee agroforestry system seem to contribute to the decrease of observed animals. Animal diver-sity in particular ecosystem is often associated with the availability of vegetation composition to provide better shelter and foods [23].

From in-depth interviews and field observation, issues related to the sustainability of coffee orchards in Banyuwangi Regency have been identified. They can be classified into economic, so- cial, and ecological problems (Table 2). The opportunities for coffee cultivation under sustainable practices are as follows: increase of organic coffee bean, increase of specialty and third-wave coffee, and rapid development of ecotourism. The increase in coffee production is also significant factor in improving coffee orchards' productivity.

\section{Coffee and tourism}

Coffee recently became an interesting attraction in tourism [24-27]. The use of coffee orchards as tourism attraction has been promoted in some countries, but few has been practiced in Indonesia. Visiting plantation has been offered as one of the interesting tourism programs in Banyuwangi Regency. Reports show that the market consists of European countries. Visiting plantation was combined with travel to Meru Betiri National Park, Alas Purwo National Park, and Ijen crater [28]. Margo Utomo Cottage in Kalibaru is one of the pioneers for such tourism program. There are no specific programs when visiting the coffee plantation, as interpreting coffee culture and enjoying coffee as a traditional beverage were the main goals of the tourism program.

Reports show that visiting coffee orchards has not developed [2, 28]. In the past, some factor contributing to the less tourism activity takes place in the rural community. The combination of available information, hospitality, infrastructure, facility, and the absence of tourism program often lead coffee tourism to less development. Farmers claimed that tourism is new culture, and rural people have poor knowledge and skill to implement tourism. According to a tourism consultant and tourism guides, local people still derive most of their income from crops' yield, while in some opportunities, peasants were potentially able to generate income from tourism. These problems seem common in tropical developing countries. Sinclair-Maragh and Gursoy pointed out that solving such problem was the main agenda in tourism developing planning [29]. A comprehensive approach with the active support of tourism stakeholder is crucial to enhance the local community capacity in tourism planning and implementation.

Challenges in integrating coffee into recent rapid tourism development come from several points. As mentioned by informants, recent protourism policy by local government allows sociopolitical support for coffee agroforestry landscapes as tourism attractions. Government of 
Banyuwangi, supported by Indonesian government and stakeholder, is very active in promoting tourism as a leading sector for economic earning and vehicle to stimulate local development. Reports show that recent growth of coffee lovers is a positive point to integrate coffee into tourism. It was supported by the growth of coffee shop in the Banyuwangi area.

\section{The future of coffee landscape in the context of Banyuwangi Geopark}

The designation of Banyuwangi Geopark was a strategy to enhance the sustainable uses of geological resources in the area. Specifically, the designation of geopark was also associated to the sustainable tourism development in Banyuwangi. This is relevant with the recent government policy to establish Banyuwangi as one of the new spots of tourism in Indonesia. Statistical data also shows that tourism in Banyuwangi has grown significantly. The tourism facility to explore Banyuwangi has been established and improved, including new airport, seaport, marina, and star hotels [30]. Banyuwangi has important geological sites in which many of them are identified important to enhance the sustainability of economic, social, and environmental system in supporting local and global community. Many of the geological sites are rare, have aesthetic value, and importance in science and education development [2].

The coffee landscape in Banyuwangi territory has contributed to its establishment as the coffee cultural heritage site. The coffee landscape of Banyuwangi has its long own history since the Dutch colonial era. Arifandi and Arifin note numerous rituals in coffee farming have deve-loped since the past decades in Banyuwangi [31]. Coffee is also considered an important beverage in most of the ritual and cultural activities among communities in Banyuwangi and its surrounding area. Recently, the intimate relationship between coffee and culture was represented by Ngopi Sepuluh Ewu Festival, which was celebrated every year in Kemiren Village, Banyuwangi [32, 33]. The recent coffee landscape in Banyuwangi represents the dynamic relations between human, its environment, and coffee cultivation knowledge (Figure $3)$.

The coffee landscapes recently received intensive discussion, represent the important of coffee landscapes in tourism and community development $[34,35]$. Local community and stakeholder participation is important. Recent threats to the sustainability of coffee landscapes should be discusse-d in the geopark management scenario. Since the landscapes are also home to numerous communities, it is crucial to consider multi-stakeholder active participation. Multi-stakeholders should be involved in the planning, implementation, and monitoring of the preservation and biodiversity conservation of coffee landscapes [36, 37].

This research recommends several aspects related to the preservation of coffee landscape and its biodiversity in Banyuwangi Regency. The future of coffee landscapes depends on the management of several issues identified in this study. Several immediate actions need to be taken as stated in the following statements.

First, it is important to map comprehensively the distribution and characterization of coffee or-

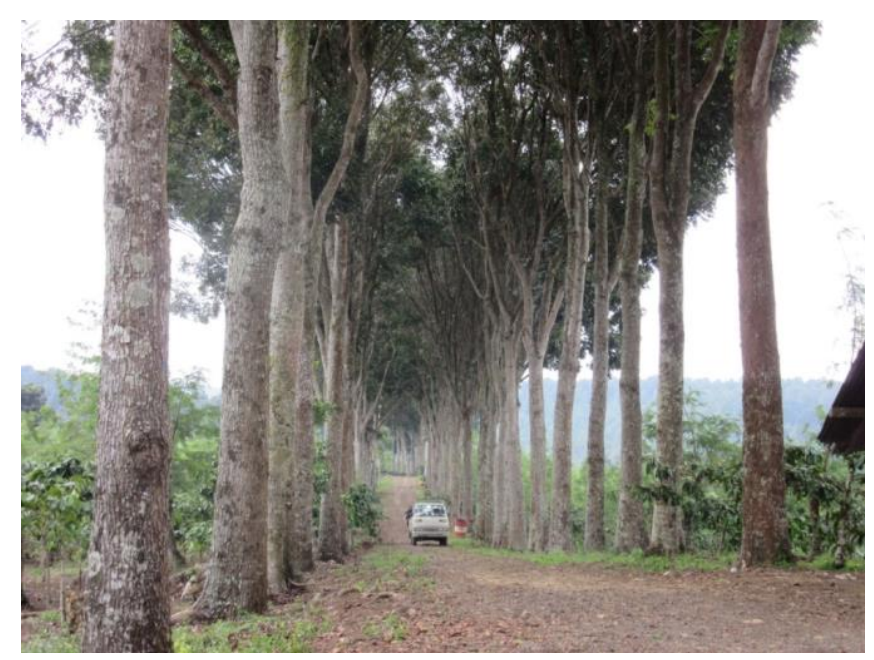

Figure 3. The landscape of Bumisari coffee plantation in Songgon, Banyuwangi 
chards. The distribution data and information of coffee landscape are especially important for planning management. The comprehensive map will allow for better understanding of coffee landscape in the context of structure and process, which are important in the preservation and biodiversity conservation efforts in the landscape. These actions will provide data on information distribution and degree of coffee landscape disturbance, which will allow for proper restoration programs to improve the ecosystem quality of coffee landscapes. In the context of tourism planning, mapping also provides information on biodiversity corridors, attraction distribution, and amenities which are crucial in supporting the spatial planning of competitive destinations [38, 39].

Second, it is important to increase coffee peasant capacity, ranging from individuals to peasant group. Training and education of best practice in the context of sustainable farming is also important to ensure the balance role of agro-forestry coffee orchards in economic, social, and environmental aspects. Regenerating old peasant to continuous coffee culture farming is important. Straightening the role of coffee peasant association is also important. Through the association, the mechanism to achieve stakeholder support and generate programs will be properly planned and monitored under comprehensive programs. The association plays an important role in distributing and sharing information, and it can also accommodate numerous interests to draw policy and actions for the community. These issues become crucial keys for the success of community-based coffee landscape preservation and biodiversity conservation $[2,40]$.

Third, it is crucial to introduce and promote tourism with economic, social, and environmental sound in balance. Tourism requires creativity and innovation to bring natural, cultural, and social capital into tourism product. It is not easy for many local communities in Banyuwangi to adopt sustainable tourism principles. However, recent increase of tourist needs to the high quality of tourism destination provides significant challe-nges for community in Banyuwangi to initiate sustainable tourism practices. The knowledge and skills of coffee peasants are especially crucial for improvement, and they should learn hospitality, entrepreneurship, and coffee cultivation techni-ques to meet high-quality standard of coffee-based tourism. It is crucial for the local government, aca- deme, and tourism stakeholders to participate in local community development programs, in order to realize sustainable tourism in Banyuwangi Regency as a land of coffee [41].

Fourth, it is important for the local government to release regulations to protect coffee landscape areas from numerous threats, which can potentially decrease and destroy coffee landscape. With the increase of vandalism and low appreciation to cultural heritages, strict regulations will serve as an instrument to minimize rapid loss of coffee landscapes and its associated attributes. Without governmental intervention in regional spatial planning and management, coffee landscapes can potentially turn to other types of land uses [42].

\section{Conclusion}

The culture to cultivate coffee has contributed to the recent coffee landscape in Banyuwangi Geopark area. Coffee agroforestry coffee system has been one of the sustainable agroforestry prac-tices observed by local peasants, contributing to the biodiversity conservation in geopark system. With the increase of tourism in Banyuwangi, there are opportunities for the promotion of coffee landscapes as an integral component of Banyuwangi Geopark as competitive and sustainable tourism destination. There are obvious benefits of integrating coffee landscapes into tourism development. Mapping and describing coffee orchard distribution, enhancing peasant capacity in coffee cultivation, introducing and strengthening sustainable tourism principles, and establishing regulations are crucial in realizing the preservation and conservation of coffee cultural landscapes in Banyuwangi Geopark.

\section{Acknowledgement}

We thank the rector of Brawijaya University for funding support. We also thank the editor and two anonymous referees for their useful comments.

\section{References}

1. Clarence-Smith WG (1994) The impact of forced coffee cultivation on Java, 1805-1917. Indonesia Circle 22(64): 241-264.

2. Hakim L (2017) Cultural landscape preservation and ecotourism development in Blambangan Biosphere Reserve, East Java. In: Hong SK, Nakagoshi N, eds. Landscape ecology for sustainable society. Tokyo, Springer. 341-358. doi:10.1007/978-3-319-74328-8_21. 
3. Hakim L, Pamungkas NR, Wicaksono KP, Soemarno S (2018) The conservation of Osingnese traditional home garden agroforestry in Banyuwangi, East Java, Indonesia. Agrivita, Journal of Agricultural Science 40(3): 506514.

4. Wellman FL (1961) Coffee: botany, cultivation, and utilization. London, L. Hill.

5. Vieira HD (2008) Coffee: The plant and its cultivation. In: Souza RM, ed. Plant-parasitic nematodes of coffee. Springer, Dordrecht. 3-18.

6. Valencia V, García-Barrios L, West P, Sterling EJ, Naeem S (2014) The role of coffee agroforestry in the conservation of tree diversity and community composition of native forests in a Biosphere Reserve. Agriculture, Ecosystems \& Environment 189: 154-163.

7. Hakim L, Siswanto D, Rahardi B, Zayadi H (2019) Fostering coffee agroforestry for agrotourism development in degraded land in a buffer zone of a national park: A case study from Poncokusumo, Malang, Indonesia. Eurasian Journal of Biosciences 13(2): 1613-1620.

8. Turner S (2006) Promoting UNESCO Global Geoparks for sustainable development in the Australian-Pacific region. Alcheringa: An Australasian Journal of Palaeontology 30(S1): 351-365.

9. Farsani NT, Coelho C, Costa C (2011) Geotourism and geoparks as novel strategies for socio-economic development in rural areas. International Journal of Tourism Research 13(1): 68-81.

10. Agriculture Office of Banyuwangi Regency (2018) Statistik perkebunan Kabupaten Banyuwangi 2018 [Plantation statistics of Banyuwangi Regency]. Statistic Center of Banyuwangi, East Java.

11. Veal AJ (1992) Research methods for leisure and tourism: A practical guide. London, Longman.

12. Shank GD (2006) Qualitative research: A personal skills approach. Upper Saddle River, NJ, Pearson Merrill Prentice Hall.

13. Evizal R, Sugiatno S, Prasmatiwi EF, Nurmayasari I (2016) Shade tree species diversity and coffee productivity in Sumberjaya, West Lampung, Indonesia. Biodiversitas, Journal of Biological Diversity 17(1): 234-240.

14. Yuliasmara F (2017) El Nino effect on coffee growth and productivity on several agroforestry systems in Gumitir Mountain Coffee Farms, East Java, Indonesia. Pelita Perkebunan 33: 168-179.

15. Priyadharsini R, Hairiah K, Suprayogo D, Baon JB (2011) Keragaman pohon penaung pada kopi berbasis agroforestry dan pengaruhnya terhadap layanan ekosistem [Diversity of shading plant tree species in agroforestry system and its implication to environmental services]. Berkala Penelitian Hayati 7F: 81-85 (in Indonesian).

16. Supriadi H, Pranowo D (2016) Prospek pengembangan agroforestri berbasis kopi di Indonesia [Prospect of coffee-based agrotourism development in Indonesia]. Perspektif 14(2): 135-150 (in Indonesian).

17. Erhart E, Hartl W (2010) Compost use in organic farming. In: Lichtfouse E, ed. Genetic Engineering, Biofertilization, Soil Quality and Organic Farming. Springer, Dordrecht. 311-345. doi: 0.1007/978-90-481-87416_11.

18. Thurston RW, Morris J, Steiman S (2013) Coffee: A comprehensive guide to the bean, the beverage, and the industry. Maryland, Rowman \& Littlefield Publishers.
19. Davis AP, Chadburn H, Moat J, O’Sullivan R, Hargreaves S, Lughadha EN (2019) High extinction risk for wild coffee species and implications for coffee sector sustainability. Science Advances 5(1): 3473.

20. Hite EB (2011) Transformations of a coffee landscape in southern Mexico: a case study of emigration and conservation in the Sierra Norte, Oaxaca. USA, Florida International University.

21. Hansen GE (2019) Agricultural and rural development in Indonesia. New York, Routledge.

22. Susilowati SH (2019) Fenomena penuaan petani dan berkurangnya tenaga kerja muda serta implikasinya bagi kebijakan pembangunan pertanian [The phenomena of old farmer and decrease of young farmer and its implication for agriculture development policy]. Forum Penelitian Agro Ekonomi 34 (1): 35-55 (in Indonesian).

23. DeWalt SJ, Maliakal SK, Denslow JS (2003) Changes in vegetation structure and composition along a tropical forest chronosequence: implications for wildlife. Forest Ecology and Management 182(1-3): 139-151.

24. Jolliffe L (2010) Coffee culture, destinations and tourism. Bristol, Channel View Publications.

25. Kleidas M, Jolliffe L (2010) Coffee attraction experiences: A narrative study. Turizam 58(1): 61-73.

26. Lyon S (2013) Coffee tourism and community development in Guatemala. Human Organization 72 (3): 188198.

27. Candelo E, Casalegno C, Civera C, Büchi G (2019) A ticket to coffee: Stakeholder view and theoretical framework of coffee tourism benefits. Tourism Analysis 24(3): 329-340.

28. Tourism Office of Banyuwangi Regency (2019) Statistik Pariwisata Kabupaten Banyuwangi 2019 [Tourism statistics of Banyuwangi Regency]. Statistic Center of Banyuwangi, East Java.

29. Sinclair-Maragh G, Gursoy D (2016). A conceptual model of residents' support for tourism development in developing countries. Tourism Planning \& Development 13(1): 1-22.

30. Irawan E (2015) Implementasi kebijakan pembangunan pariwisata di Kabupaten Banyuwangi [The implication of tourism development policy in Banyuwangi Regency]. Jejaring Administrasi Publik 7(2): 757-770 (in Indonesian).

31. Arifandi JA, Arifin DE (2013) Kajian sosial budaya dan perekonomian masyarakat di perkebunan kopi [Studies on socio-cultural and economic of community on coffee plantation], Jember University, East Java.

32. Prasetyo H (2015) Absorpsi cultural: fetishisasi komoditas kopi [Cultural absorption: Fetishism in coffee commodity]. Literasi: Indonesian Journal of Humanities 4(2): 196-206 (in Indonesian).

33. Zulfikar F, Purwanta H (2020) Gastro-kosmopolitan dalam kopi Osing [Gastro-cosmopolitan in Osingnese coffee]. Historika 23(1): 119-132 (in Indonesian).

34. Orjuela A, Escobar DA, Moncada CA (2020) Conditions of territorial accessibility offered by the network of sustainable tourism routes that are part of the coffee cultural landscape - Colombia. Geojournal of Tourism and Geosites 32(4): $1290-1298$. doi: 10.30892/GTG.32415-571.

35. Muñiz-Martínez N. (2016) Towards a network place branding through multiple stakeholders and based on 
cultural identities: The case of "The Coffee Cultural Landscape in Colombia.” Journal of Place Management and Development 9(1): 73-90.

36. Selman P (2004) Community participation in the planning and management of cultural landscapes. Journal of Environmental Planning and Management 47(3): 365392.

37. Stenseke M (2009) Local participation in cultural landscape maintenance: Lessons from Sweden. Land Use Policy 26(2): 214-223.

38. Hakim L (2017). Managing biodiversity for a competitive ecotourism industry in tropical developing countries: New opportunities in biological fields. In AIP Conference Proceedings November 2017 AIP Publishing LLC. 1908(1): 030008.
39. Metternicht G (2018) Land use and spatial planning: Enabling sustainable management of land resources. Springer.

40. Londoño JLI, Silva CAV (2018) Sustainable development and nature-culture linkages in the Coffee Cultural Landscape of Colombia. In World heritage and sustainable development. Routledge. 226-239.

41. Turner S (2006) Promoting UNESCO Global Geoparks for sustainable development in the Australian-Pacific region. Alcheringa: An Australasian Journal of Palaeontology 30(S1): 351-365

42. Hudalah D, Woltjer J (2007) Spatial planning system in transitional Indonesia. International Planning Studies 12(3): 291-303. 